\title{
What have we learned?
}

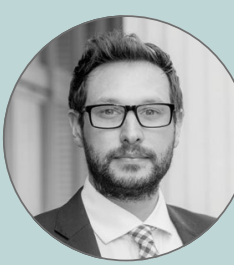

\section{David Westgarth}

Editor, BDJ in Practice

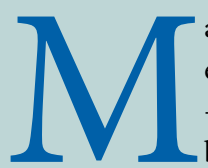

any of you reading this will either know - or be aware of - the name Colin Kaepernick, but you may not know why you know that name. I predict even less of you will know who Nate Boyer is, and how pivotal his thoughts would prove to be in shaping the background to the discourse throughout 2020.

When Kaepernick decided in August 2016 to sit down during the national anthem at an NFL preseason game between his team the San Francisco 49ers and the Green Bay Packers, it divided the sport and people across the United States. Former President Trump equated not standing for the anthem with disrespecting the American flag, saying at a rally 'Wouldn't you love to see one of these NFL owners, when somebody disrespects our flag, to say, 'Get that son of a bitch off the field right now. Out! He's fired. He's fired!"

Kaepernick's gesture made former Green Beret Boyer upset. In an open letter to Kaepernick, he admitted he had been angry at Kaepernick sitting down during the anthem but that he respected the player's right to protest. It was after Kaepernick reached out to Boyer to arrange a meeting that things began to change. Both parties wanted to listen to the other, to share and to learn. Boyer stood his ground - he did not wish to

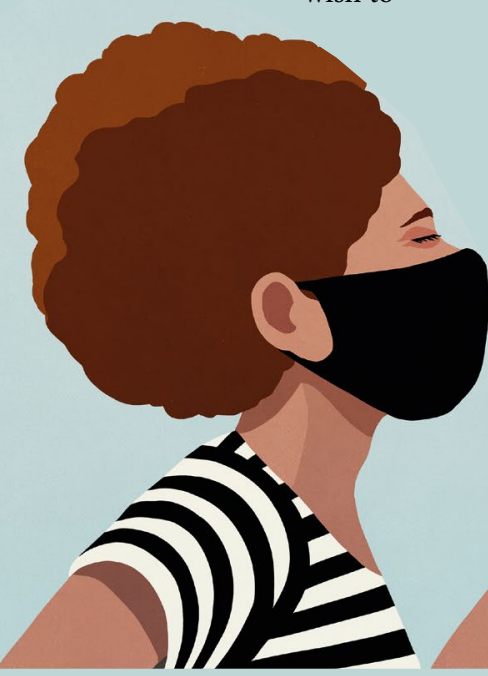

imitate any gesture Kaepernick would do, and Kaepernick stood his - he was committed to not standing. And so, Boyer suggested Kaepernick take the knee. He wouldn't do it himself, but he would stand beside him, in solidarity with Kaepernick and team-mate Eric Reid. Taking the knee was born.

What followed was an open a public disconnect between the NFL team owners, executives, coaches and players. The anthem would start and players would take the knee, stay in the locker room, show acts of solidarity, all to a cacophony of boos. Trump continued to wade in, and the NFL moved to ban the gesture two years later. Kaepernick has not played a competitive game for any team since he took the knee surrounded by Reid and Boyer on 1 September, 2016.

So why is this even remotely relevant?

From the moment Kaepernick decided to sit and eventually kneel, right through to present day dialogue about sportspeople taking or not taking the knee before a game, education was, is and forever will be at the heart of it. Kaepernick has said on numerous occasions that the sole purpose of kneeling during the national anthem was not to disrespect military personnel, but rather that his goal was to use his social platform to bring topics regarding police brutality and oppression of people of colour to light. After the murder of George Floyd in America in 2020, many protesting police brutality took the knee, and the Black Lives Matter movement grew. In the intervening months, those ignorant to or unwilling to - educate themselves about where that gesture and movement derived from said all manner of things that showed the extent of how overlooked systemic racism and inequality was in this country.
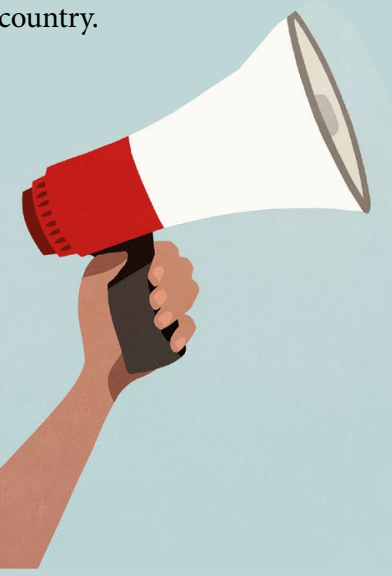

Which brings me back to education. If we don't encounter the barriers experienced by those from minority backgrounds, that doesn't mean we shouldn't learn about them. Take the recent webinar hosted by the FGDP(UK) and ProDentalCPD on gender equality in dentistry. What should have been an opportunity to reflect and learn from some excellent speakers was soured by two individuals who 'dominated the chat forum with a continual barrage of inflammatory and inappropriate postings', a message to participants read. The message went on to say 'We have received apologies from the individuals concerned, and hope that the experience of the last few days leads to reflection on their part and precipitates a change in attitude and behaviour.

There will no doubt be those who attended the forum who will come away thinking anyone complaining is nothing but a 'woke liberal' and chalk it down to 'banter'. There will be those who do not pick up this issue or do not read past this editorial knowing the focus is on matters of diversity. There are those who think this is too little too late after one author's 'filled the gap' comment. There are those who think this is rich coming from the $\mathrm{BDA}$ when its board is regarded by some as not representative of the demographic of the profession it serves. Whether you or I agree with these sentiments or not, the key word once again is education.

I've heard it said that our first thoughts are our conditioning and our second thoughts are our learning. Forgive yourself your first thoughts if you are pausing, reflecting, correcting; the point is that you are learning. Then you can begin to ask yourself about how you could be an ally to minority groups. To coin a recent phrase 'be more Nate Boyer'.

Do you know the BDA is a trade union and therefore its Principal Executive Committee cannot protect seats based on protected characteristics? Do you know unions have to use paper voting, even in this day and age? Do you know why that author chose the language he did about the acting female $\mathrm{CEO}$ ? Do you know why the professions needed a webinar devoted to gender issues? Do you know why you're not interested in reading about the experience of others?

Maybe the time to learn, is now. * https://doi.org/10.1038/s41404-021-0673-z 